\title{
The Relationship Between Airway Occlusion Pressure and Severity of Liver Cirrhosis in Candidates for Liver Transplantation
}

\author{
Delara Gholamipoor ${ }^{1}$, Mohssen Nassiri-Toosi ${ }^{2}$, Masumeh Azadi ${ }^{3}$, Mehrnaz Asadi Gharabaghi ${ }^{4, *}$
}

1. Resident of Internal Medicine, Imam Khomeini Hospital Complex, Tehran University of Medical Sciences, Tehran, Iran

2. Liver Transplantation Research Center, Tehran University of Medical Sciences, Tehran, Iran

3. Imam Khomeini Hospital Complex, Tehran University of Medical Sciences, Tehran, Iran

4. Thoracic Research Center, Imam Khomeini Hospital, Tehran University of Medical Sciences, Tehran, Iran

\section{* Corresponding Author:}

Mehrnaz Asadi Gharabaghi, MD Associate Professor of Pulmonary and Critical Care Department, Thoracic Research Center, Imam Khomeini Hospital, Tehran University of Medical Sciences, Tehran, Islamic Republic of Iran

Telefax: + 982161192646

Email: asadi_m@tums.ac.ir

Received: 08 Sep. 2019

Accepted: 02 Mar. 2020

\section{ABSTRACT}

\section{BACKGROUND}

End-stage cirrhosis is an irreversible condition, and liver transplantation is the only treatment option in for the affected patients. Respiratory problems and abnormal breathing are common findings among these patients. In this study, for the first time, we examined the relationship between the severity of liver cirrhosis and respiratory drive measured by mouth occlusion pressure $\left(\mathrm{P}_{0.1}\right)$.

\section{METHODS}

This was a cross-sectional study conducted on 50 candidates for liver transplantation who were referred to the pulmonary clinic of Imam Khomeini Hospital for pre-operative pulmonary evaluations. Arterial blood gas analysis (ABG), pulmonary function tests, and measurement of $\mathrm{P}_{01}$ were performed for all patients. The severity of liver disease was assessed using the Model for End-Stage Liver Disease (MELD) score.

\section{RESULTS}

The median $\mathrm{P}_{0,1}$ was $5 \mathrm{~cm} \mathrm{H} \mathrm{H}_{2}$. $\mathrm{P}_{0.1}$ was negatively associated with $\mathrm{PaCO}_{2}(\mathrm{r}=-0.466, p=0.001)$ and $\mathrm{HCO}_{3}-(\mathrm{r}=-0.384, p=0.007)$, and was positively correlated with forced expiratory volume at $1 \mathrm{~s}$ $\left(\mathrm{FEV}_{1}\right) /$ forced vital capacity $(\mathrm{FVC})(\mathrm{r}=0.282, p=0.047)$. There was a strong correlation between $\mathrm{P}_{0.1}$ and MELD score $(\mathrm{r}=0.750, p<0.001)$. Backward multivariate linear regression revealed that a higher MELD score and lower $\mathrm{PaCO}_{2}$ were associated with increased $\mathrm{P}_{0.1}$.

\section{CONCLUSION}

High levels of $\mathrm{P}_{0.1}$ and strong direct correlation between $\mathrm{P}_{0.1}$ and MELD score observed in the present study are suggestive of the presence of abnormal increased respiratory drive in candidates for liver transplantation, which is closely related to their disease severity.

\section{KEYWORDS:}

Cirrhosis, MELD score, Pulmonary, Spirometry, Airway occlusion pressure

\section{Please cite this paper as:}

Gholamipoor D, Nassiri-Toosi M, Azadi M, Asadi Gharabaghi M. The Relationship Between Airway Occlusion Pressure and Severity of liver Cirrhosis in Candidates for Liver Transplantation. Middle East J Dig Dis 2020;12:111-115. doi: 10.34172/mejdd.2020. 170.

\section{INTRODUCTION}

Liver transplantation is the best therapeutic strategy for patients with decompensated cirrhosis. ${ }^{1,2}$ Pulmonary complications and respiratory problems are common among these patients. They frequently complain about breathlessness and dyspnea. Several conditions associated with end-stage cirrhosis such as tense ascites, pleural effusion, interstitial pulmonary edema, and respiratory muscles wasting may contribute to pulmonary problems in patients 
with cirrhosis. ${ }^{3}$ Pulmonary complications are also common after liver transplantation and are associated with increased morbidity and mortality. Some previous studies have shown that respiratory problems and some breathing patterns prior to surgery are predictors of post-operation pulmonary complications. ${ }^{4,5}$

Candidates for liver transplantation routinely undergo a thorough pulmonary assessment before surgery. Pulmonary function tests (PFTs) are usually within normal ranges in these patients. ${ }^{5}$ Gas exchange abnormalities are common findings, which can be attributed to decreased total lung capacity, obstructive and restrictive types of abnormalities, gas diffusion impairment, and pulmonary vascular problems in patients with end-stage cirrhosis. ${ }^{67}$ However, the exact etiology of respiratory abnormalities in liver cirrhosis is still unknown, and further studies are needed to investigate the related contributing factors.

Measurement of the airway occlusion pressure $0.1 \mathrm{sec}$ after the onset of inspiratory flow $\left(\mathrm{P}_{0.1}\right)$ is a useful method for the assessment of respiratory motor output. ${ }^{8}$ Higher $\mathrm{P}_{0.1}$ values are suggestive of greater respiratory effort and increased dyspnea scores. ${ }^{9}$ To our knowledge, no prior study has evaluated the respiratory drive in patients with liver cirrhosis. We conducted this study to evaluate the respiratory drive and its association with disease severity in candidates for liver transplantation who suffer from endstage liver cirrhosis.

\section{MATERIALS AND METHODS}

\section{Study Population}

Consecutive male and female patients with end-stage liver cirrhosis, candidates for liver transplantation, who referred for preoperative respiratory evaluations were evaluated for eligibility. Inclusion criteria were: age $\geq 18$ years, definitive diagnosis of liver cirrhosis according to clinical, histological, biochemical, and ultrasonographic findings, and normal respiratory muscle function evaluated by maximal inspiratory mouth pressure (PIMAX) measurement. Patients were excluded if they had any history of cardiac or respiratory diseases, active infectious disease, fever, smoking, or any other major medical conditions that could interfere with normal pulmonary function.

The protocol of this study was reviewed and approved by the Ethics Committee of Tehran University of Medical Sciences. All patients signed informed consent before enrollment to the study.

All included patients underwent a thorough physical examination, and their demographic and clinical data were recorded. Disease severity was assessed according to the Model for End-Stage Liver Disease (MELD) scale, ${ }^{10}$ which is calculated based on laboratory values for serum creatinine, bilirubin, and the international normalized ratio (INR). Arterial blood gas (ABG) analyses were done before spirometry while patients were at rest and breathing room air. Blood oxygen saturation was assessed with pulse oximetry.

\section{Pulmonary Function Tests}

PFTs were performed in the sitting position using clinical spirometry (Ganshorn Powercube LF8 .5K SR1, Germany). Forced vital capacity (FVC), forced expiratory volume at 1s (FEV1), and FEV1/FVC were obtained as recommended by the American Thoracic Society. ${ }^{11}$

Using the body plethysmography device, $\mathrm{P}_{0.1}$ was measured $100 \mathrm{~ms}$ after the onset of inspiration at rest. ${ }^{8,12}$ $\mathrm{P}_{0.1}$ was expressed as an absolute value $\left(\mathrm{cm} \mathrm{H}_{2} \mathrm{O}\right)$.

\section{Statistical Analysis}

All statistical analyses were performed using the Statistical Package for the Social Sciences (SPSS) version 25. Continuous variables were expressed as mean \pm standard deviation (SD) or median (interquartile range) as appropriate. The association between variables was examined using the Pearson correlation test. The association between $\mathrm{P}_{0.1}$ and MELD score and potential confounders was investigated with backward multivariate linear regression. The level of significance was considered as $p<0.05$.

\section{RESULTS}

A total of 50 patients with liver cirrhosis who were at the top of the liver transplantation waiting list were included. The demographic and clinical characteristics of the patients are shown in table 1. An acid-base disturbance was detected in 35 (70\%) patients. The type of acid-base disorders was respiratory alkalosis in $10(20 \%)$, metabolic alkalosis in 12 (24\%), a mixed acid-base disorder in 12 $(24 \%)$, and metabolic acidosis in $1(2 \%)$ patients. All but 
Table 1: Demographic and clinical characteristics of the candidates for liver transplantation

\begin{tabular}{lc}
\hline Variables & Values \\
\hline Age (y) & $49.1 \pm 13.0$ \\
\hline Male sex, n (\%) & $36(72)$ \\
\hline Etiology, n (\%) & \\
& \\
Hepatitis B virus infection & $14(28)$ \\
Hepatitis C virus infection & $2(4)$ \\
Autoimmune hepatitis & $7(14)$ \\
Non-alcoholic fatty liver disease & $7(14)$ \\
Cryptogenic & $5(10)$ \\
Others & $11(22)$ \\
\hline Underlying disease duration $(\mathrm{y})$ & $4(2-10)$ \\
\hline MELD & $19.6 \pm 2.9$ \\
\hline Arterial blood gas & \\
$\mathrm{SpO}_{2}$ & \\
$\mathrm{PaCO}_{2}$ & $96.6 \pm 2.2(\%)$ \\
$\mathrm{HCO}_{3}-$ & $37.6 \pm 6.2(\mathrm{mmHg})$ \\
$\mathrm{pH}^{-}$ & $26.6 \pm 4.6(\mathrm{meq} / \mathrm{L})$ \\
\hline
\end{tabular}

Spirometry

FVC (liters)

FVC (\% of predicted)

FEV (liters)

$\mathrm{FEV}_{1}(\%$ of predicted)

$\mathrm{FEV}, / \mathrm{FVC}$

$\mathrm{P}^{0.1}\left(\mathrm{cmH}_{2} \mathrm{O}\right)$

MELD: model for end satge liver disease, $\mathrm{SpO} \cdot$ oxygen saturation measured by pulse, $\mathrm{PaCO}$ : arterial $\mathrm{CO}_{2}$ pressure, $\mathrm{HCO}_{3}$ : blood bicarbonate level.pH: the index of blood acidic or basic status, $\mathrm{FVC}$ : forced vital capacity volume, $\mathrm{FEV}$ : forced expiratory volume in first second of expiration, $\mathrm{FEV} / \mathrm{FVC}$ : index of expiratory flow rate, $\mathrm{P}_{0.1}$ : cetral respiratory drive pressure.

one patient had an $\mathrm{FEV}_{1} / \mathrm{FVC}$ ratio greater than $70 \%$. The $\mathrm{P}_{0.1}$ ranged from 1 to $9 \mathrm{~cm} \mathrm{H}_{2} \mathrm{O}$ among our patients. The median $\mathrm{P}_{0.1}$ was $5 \mathrm{~cm} \mathrm{H}_{2} \mathrm{O}$.

Among the $\mathrm{ABG}$ parameters, $\mathrm{P}_{0.1}$ was negatively associated with $\mathrm{PaCO}_{2}(\mathrm{r}=-0.466, p=0.001)$ and $\mathrm{HCO}_{3}-$ $(\mathrm{r}=-0.384, p=0.007) . \mathrm{P}_{0.1}$ was positively correlated with $\mathrm{FEV}_{1} / \mathrm{FVC}(\mathrm{r}=0.282, p=0.047)$. There was no other significant association between $\mathrm{P}_{0.1}$ and spirometry variables. There was a strong correlation between $\mathrm{P}_{0.1}$ and MELD score $(\mathrm{r}=0.750, p<0.001)$ (figure 1 ).

Backward multivariate linear regression was used to identify the predictors of $\mathrm{P}_{0.1}$ (the final model is shown in table 2). Greater MELD score and lower $\mathrm{PaCO}_{2}$ were associated with increased $\mathrm{P}_{0.1}$. Age and $\mathrm{FEV}_{1} / \mathrm{FVC}$ ratio were also independent predictors of $\mathrm{P}_{0.1}$.

\section{DISCUSSION}

Here, for the first time, we examined the relationship between the severity of liver cirrhosis and respiratory drive measured by $\mathrm{P}_{0.1}$. As we mentioned earlier, $\mathrm{P}_{0.1}$ is a
Table 2: Predictors of $\mathbf{P}_{0.1}$ in candidates for liver transplantation with advanced cirrhosis

\begin{tabular}{lcccc}
\hline \multirow{2}{*}{ Model } & \multirow{4}{c}{$\begin{array}{c}95 \% \text { Confidence } \\
\text { Interval for } \mathbf{B}\end{array}$} & \multirow{2}{*}{$\boldsymbol{p}$ value } \\
\cline { 3 - 4 } & & $\begin{array}{c}\text { Lower } \\
\text { Bound }\end{array}$ & $\begin{array}{c}\text { Upper } \\
\text { Bound }\end{array}$ & \\
\hline Age & -.034 & -.058 & -.009 & 0.008 \\
\hline $\mathrm{Sex}$ & .817 & -.034 & 1.669 & 0.059 \\
\hline $\mathrm{MELD}$ & .312 & .167 & .456 & $<0.001$ \\
\hline $\mathrm{FEV}_{1} / \mathrm{FVC}$ & 11.696 & 5.550 & 17.843 & 0.001 \\
\hline $\mathrm{PaCO}_{2}$ & -.088 & -.143 & -.032 & 0.003 \\
\hline
\end{tabular}

MELD: model for end satge liver disease, $\mathrm{PaCO}$ :arterial $\mathrm{CO} 2$ pressure, $\mathrm{FEV} 1 / \mathrm{FVC}$ index of expiratory flow rate,P0.1: cetral respiratory drive pressure.

measurable index of respiratory motor output. Previous studies on healthy adults demonstrated that normal $\mathrm{P}_{0.1}$ was usually lower than $2 \mathrm{~cm} \mathrm{H} \mathrm{H}_{2} \mathrm{O} \cdot{ }^{13,14}$ Higher $\mathrm{P}_{0.1}$ implies excessive respiratory effort. The median $\mathrm{P}_{0.1}$ in candidates for liver transplantation in this study was $5 \mathrm{~cm} \mathrm{H}_{2} \mathrm{O}$, which is similar to the values reported for stable nonintubated patients with COPD. ${ }^{15}$

We found a strong direct correlation between $\mathrm{P}_{0.1}$ and MELD score. Moreover, the MELD score was an independent predictor of $\mathrm{P}_{0.1}$. This finding may indicate that as the severity of cirrhosis increases, the respiratory drive and effort increase in these patients. Some previous studies have evaluated the association between MELD score and dyspnea, respiratory muscle strength, and lung function in candidates for liver transplantation. ${ }^{16,17}$ In a study conducted by Kaltsakas and colleagues the correlations between MELD score and chronic dyspnea and respiratory muscle strength indices were evaluated in patients with endstage liver disease waiting for liver transplantation. ${ }^{16}$ The authors found that MELD score was positively correlated with chronic dyspnea and both were negatively correlated with respiratory muscle strength indices. ${ }^{16}$ These findings were confirmed in another study by Abdel-bary and coworkers in Egypt. ${ }^{18}$

Inspiratory effort sensation has a key role in the perception of breathlessness and voluntary regulation of ventilation. Previous studies have shown that there is a tight correlation between inspiratory effort sensation and $\mathrm{P}_{0.1}$ and $\mathrm{PCO}_{2}$ in normal humans. ${ }^{19}$ Hypercapnia triggers the central respiratory center and increases the respiratory motor output and $\mathrm{P}_{0.1} \cdot{ }^{19} \mathrm{We}$ found a significant negative correlation between $\mathrm{P}_{0.1}$ and $\mathrm{PaCO}_{2}$ in our patients. This may suggest that patients with lower $\mathrm{PaCO}_{2}$ may have 


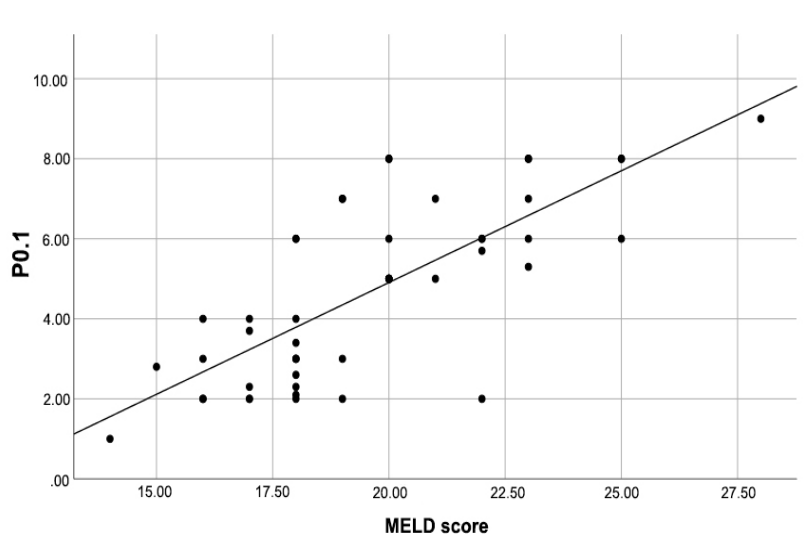

Fig.1: Correlation between $P_{0.1}$ and MELD score

increased levels of $\mathrm{P}_{0.1}$. Decreased $\mathrm{PaCO}_{2}$ and respiratory alkalosis is the most common acid-base disorder among patients with cirrhosis. ${ }^{20-22}$ The exact cause of abnormal hyperventilation in these patients is still unknown. However, several factors such as hyperamonia, acities, hepatopulmonary syndrome, increased chemosensitivity to $\mathrm{CO}_{2}$ and hypoxia, and impaired metabolism of progesterone and estradiol may contribute to hyperventilation in patients with decompensated cirrhosis. ${ }^{21,23,24}$

Respiratory muscle weakness and elevated diaphragm due to ascites are two important reasons for hyperventilation in patients with cirrhosis. ${ }^{25}$ A prior study has shown that inspiratory muscle fatigue is associated with increased $\mathrm{P}_{0.1}$ in normal subjects. ${ }^{26}$ Increased $\mathrm{P}_{0.1}$ was also observed in patients with other diseases that cause decreased respiratory muscle strength and dyspnea. ${ }^{27-31}$ In a study by Huang and colleagues, the effect of inspiratory muscle strength training (IMST) on inspiratory motor drive measured by $\mathrm{P}_{0.1}$ was evaluated in healthy subjects. ${ }^{32}$ The authors showed that IMST increased maximal inspiratory pressure (MIP) significantly, which was also associated with decreased $\mathrm{P}_{0.1}{ }^{32}$

We think abnormal hyperventilation in cirrhosis is responsible for the inverse correlation between $\mathrm{PaCO}_{2}$ and $\mathrm{P}_{0.1}$ that was found in our study. Hyperventilation cause respiratory muscle weakness, which leads to increased respiratory motor output and $\mathrm{P}_{0.1}$.

In conclusion, respiratory motor output is increased among candidates for liver transplantation with end-stage liver cirrhosis. This implies excessive respiratory effort in these patients. We found a strong direct correlation between $\mathrm{P}_{0.1}$ and MELD score. Therefore, the increased respiratory drive could be related to the severity of the disease. We found a significant negative correlation between $\mathrm{P}_{0.1}$ and $\mathrm{PaCO}_{2}$ in our patients. This may suggest that patients with lower $\mathrm{PaCO}_{2}$ may have increased levels of $\mathrm{P}_{0.1}$. Abnormal hyperventilation in cirrhosis may be responsible for this finding. Hyperventilation causes respiratory muscle weakness that can lead to increased respiratory motor output and $\mathrm{P}_{0.1}$. Further studies with larger sample sizes and more robust designs are needed to understand the clinical significance of $\mathrm{P}_{0.1}$ in patients with end-stage liver disease and its relation to liver transplantation outcome.

\section{ETHICAL APPROVAL}

There is nothing to be declared.

\section{CONFLICT OF INTEREST}

The authors declare no conflict of interest related to this work.

\section{REFERENCES}

1. Jadlowiec CC, Taner T. Liver transplantation: Current status and challenges. World J Gastroenterol 2016;22:4438-45. doi: 10.3748/wjg.v22.i18.4438.

2. Haydon GH, Neuberger J. Liver transplantation of patients in end-stage cirrhosis. Baillieres Best Pract Res Clin Gastroenterol 2000;14:1049-73. doi: 10.1053/bega.2000.0146.

3. Yeshua H, Blendis LM, Oren R. Pulmonary manifestations of liver diseases. Semin Cardiothorac Vasc Anesth 2009;13:60-9. doi: 10.1177/1089253209334615.

4. Kia L, Cuttica MJ, Yang A, Donnan EN, Whitsett M, Singhvi A, et al. The utility of pulmonary function testing in predicting outcomes following liver transplantation. Liver Transpl 2016;22:805-11. doi: 10.1002/1t.24426.

5. Bozbas SS, Yilmaz EB, Dogrul I, Ergur FO, Savas N, Eyuboglu F, et al. Preoperative pulmonary evaluation of liver transplant candidates: results from 341 adult patients. Ann Transplant 2011;16:88-96. doi: 10.12659/aot.882000.

6. Krowka MJ, Dickson ER, Wiesner RH, Krom RA, Atkinson B, Cortese DA. A prospective study of pulmonary function and gas exchange following liver transplantation. Chest 1992;102:1161-66. doi: 10.1378/chest.102.4.1161.

7. Roque L, Sankarankutty AK, Silva OC Jr, Mente ED. Evaluation of Lung Function in Liver Transplant Candidates. Transplant Proc 2018;50:762-765. doi: 10.1016/j. transproceed.

8. Whitelaw WA, Derenne JP, Milic-Emili J. Occlusion pressure as a measure of respiratory center output $\mathrm{cm}$ conscious man. Respir Physiol 1975;23:181-99. doi: 10.1016/00345687(75)90059-6.

9. Torchio R, Gulotta C, Greco-Lucchina P, Perboni A, 
Montagna L, Guglielmo M, et al. Closing capacity and gas exchange in chronic heart failure. Chest 2006;129:1330-6. doi: 10.1378/chest.129.5.1330.

10. Kamath PS, Kim WR. The model for end-stage liver disease (MELD). Hepatology 2007;45:797-805. doi: 10.1002/ hep. 21563 .

11. Hankinson J. Standardization of spirometry. American Thoracic Society. Am J Respir Crit Care Med 2011;152:11071136.

12. Whitelaw WA, Derenne JP. Airway occlusion pressure. $J$ Appl Physiol (1985) 1993;74:1475-83. doi: 10.1152/jappl.1993.74.4.1475.

13. Kera T, Aihara A, Inomata T. Reliability of airway occlusion pressure as an index of respiratory motor output. Respir Care 2013;58:845-9. doi: 10.4187/respcare.01717.

14. Tobin M, Gardner W. Monitoring of the control of breathing Principles and practice of intensive care monitoring New York: McGraw-Hill. 1998:415-464.

15. Telias I, Damiani F, Brochard L. The airway occlusion pressure (P0.1) to monitor respiratory drive during mechanical ventilation: increasing awareness of a not-so-new problem. Intensive Care Med 2018;44:1532-1535. doi: 10.1007/s00134-018-5045-8.

16. Kaltsakas G, Antoniou E, Palamidas AF, Gennimata SA, Paraskeva P, Smyrnis A, et al. Dyspnea and respiratory muscle strength in end-stage liver disease. World J Hepatol 2013;5:56-63. doi: 10.4254/wjh.v5.i2.56.

17. Yigit IP, Hacievliyagil SS, Seckin Y, Oner RI, Karincaoglu M. The relationship between severity of liver cirrhosis and pulmonary function tests. Dig Dis Sci 2008;53:1951-6. doi: 10.1007/s10620-007-0100-2.

18. Abdel-bary SA, Yousif M, Hussein HA. Respiratory muscle strength, hypoxemia and dyspnea in liver cirrhosis patients. Egypt J Chest Dis Tuberc 2014;63:1059-64. doi: 10.1016/j.ejcdt.2014.06.016.

19. Clague JE, Carter J, Pearson MG, Calverley PM. Relationship between inspiratory drive and perceived inspiratory effort in normal man. Clin Sci (Lond) 1990;78:493-6. doi: $10.1042 / \operatorname{cs} 0780493$

20. Henriksen JH, Bendtsen F, Moller S. Acid-base disturbance in patients with cirrhosis: relation to hemodynamic dysfunction. Eur J Gastroenterol Hepatol 2015;27:920-7. doi: 10.1097/MEG.0000000000000382.

21. Jiménez JV, Carrillo-Pérez DL, Rosado-Canto R, GarcíaJuárez I, Torre A, Kershenobich D, et al. Electrolyte and Acid-Base Disturbances in End-Stage Liver Disease: A Physiopathological Approach. Dig Dis Sci 2017;62:18551871. doi: 10.1007/s10620-017-4597-8.

22. Scheiner B, Lindner $G$, Reiberger $T$, Schneeweiss B, Trauner M, Zauner C, et al. Acid-base disorders in liver disease. J Hepatol 2017;67:1062-73. doi: 10.1016/j. jhep.2017.06.023.

23. Passino C, Giannoni A, Mannucci F, Prontera C, Filipponi $\mathrm{F}$, Carrai $\mathrm{P}$, et al. Abnormal hyperventilation in patients with hepatic cirrhosis: Role of enhanced chemosensitivity to carbon dioxide. Int $J$ Cardiol 2012;154:22-6. doi: 10.1016/j.ijcard.2010.08.066.

24. Lustik SJ, Chhibber AK, Kolano JW, Hilmi IA, Henson LC, Morris MC, et al. The hyperventilation of cirrhosis: progesterone and estradiol effects. Hepatology 1997;25:558. doi: 10.1002/hep.510250110.

25. Scheiner B, Lindner G, Reiberger T, Schneeweiss B, Trauner M, Zauner C, et al. Acid-base disorders in liver disease. J Hepatol 2017;67:1062-1073. doi: 10.1016/j. jhep.2017.06.023.

26. Clague JE, Carter J, Pearson MG, Calverley PM. Effect of sustained inspiratory loading on respiratory sensation and $\mathrm{CO} 2$ responsiveness in normal humans. Clin Sci (Lond) 1996;91:513-8. doi: 10.1042/cs0910513.

27. Ambrosino N, Opasich C, Crotti P, Cobelli F, Tavazzi L, Rampulla C. Breathing pattern, ventilatory drive and respiratory muscle strength in patients with chronic heart failure. Eur Respir J 1994;7:17-22. doi: 10.1183/09031936.94.07010017.

28. Ferrari K, Goti P, Duranti R, Iandelli I, Misuri G, Mancini $\mathrm{M}$, et al. Breathlessness and control of breathing in patients with COPD. Monaldi Arch Chest Dis 1997;52:18-23.

29. Scott GC, Burki NK. The relationship of resting ventilation to mouth occlusion pressure. An index of resting respiratory function. Chest 1990;98:900-6. doi: 10.1378/ chest.98.4.900.

30. Gorini M, Ginanni R, Spinelli A, Duranti R, Andreotti L, Scano G. Inspiratory muscle strength and respiratory drive in patients with rheumatoid arthritis. Am Rev Respir Dis 1990;142:289-94. doi: 10.1164/ajrccm/142.2.289.

31. El-Gamal H, Khayat A, Shikora S, Unterborn JN. Relationship of dyspnea to respiratory drive and pulmonary function tests in obese patients before and after weight loss. Chest 2005;128:3870-4. doi: 10.1378/chest.128.6.3870.

32. Huang CH, Martin AD, Davenport PW. Effect of inspiratory muscle strength training on inspiratory motor drive and RREP early peak components. J Appl Physiol (1985) 2003;94:462-8. doi: 10.1152/japplphysiol.00364. 